\title{
Analisis Pemilihan Jenis Perkerasan Jalan untuk Perbaikan Kerusakan Perkerasan Jalan di Jalan Harun Thohir, Kecamatan Gresik, Kabupaten Gresik, Jawa Timur
}

\author{
Stella Tannia Daksa dan Catur Arif Prastyanto \\ Departemen Teknik Sipil, Institut Teknologi Sepuluh Nopember (ITS) \\ Corresponding Author: catur_ap@ce.its.ac.id
}

\section{ARTIKEL INFO}

\section{Informasi Artikel}

Artikel masuk: 6-8-19

Artikel revisi: 26-12-19

Artikel diterima: 26-12-19

\section{Kata Kunci}

Analisis Biaya, Karakteristik Lalu Lintas, Perkerasan Kaku, Perkerasan Lentur, Perkerasan Paving Block.

\section{ABSTRAK}

Jalan Harun Thohir di Kecamatan Gresik, Kabupaten Gresik, Jawa Timur adalah salah satu akses menuju kawasan Pelabuhan Gresik dengan kelas jalan kabupaten. Jalan sepanjang kurang lebih $1,2 \mathrm{~km}$ ini mengalami kerusakan berupa jalan yang bergelombang, berlubang, dan konstruksi beton yang hancur. Kerusakan-kerusakan ini ditengarai disebabkan oleh muatan berlebih dari kendaraan yang melalui jalan tersebut, yang tidak sesuai dengan perencanaan awal. Kerusakan-kerusakan ini menimbulkan ketidaknyamanan bagi pengendara dan masyarakat sekitar, sehingga perlu dilakukan perbaikan konstruksi perkerasan jalan. Saat ini, jalan menggunakan perkerasan kaku dan ingin dilakukan perencanaan perbaikan kerusakan perkerasan jalan dengan membandingkan penggunaan perkerasan lentur, perkerasan kaku, dan perkerasan paving block pada seksi yang sama. Perencanaan tebal struktur perkerasan lentur menggunakan metode Bina Marga 2017 dengan usia rencana 20 tahun. Perencanaan tebal struktur perkerasan kaku menggunakan metode Bina Marga 2017 dengan usia rencana 40 tahun. Sedangkan perencanaan tebal struktur perkerasan paving block menggunakan metode modifikasi perkerasan lentur, metode australian empiris, dan mechanistic design dengan usia rencana 20 tahun. Dalam perencanaan perbaikan kerusakan perkerasan jalan ini hanya digunakan data sekunder, berupa data jumlah penduduk, data PDRB, data PDRB per kapita, data lalu lintas, data curah hujan, dan data HSPK. Data tersebut diolah kemudian dilakukan analisis. Pertama, dilakukan peninjauan karakteristik lalu lintas pada saat ini dan pada umur rencana. Kemudian, dilakukan perencanaan tebal struktur perkerasan jalan dan dilakukan pula analisis biaya. Terakhir, dipilih jenis perkerasan jalan yang paling sesuai ditinjau dari segi biaya konstruksi dan pemeliharaan. Berdasarkan hal di atas, diperoleh hasil perkerasan kaku sebagai perbaikan kerusakan perkerasan jalan di Jalan Harun Thohir, Kecamatan Gresik, Kabupaten Gresik, Jawa Timur, dengan tebal lapis drainase $15 \mathrm{~cm}$, lapis pondasi LMC $10 \mathrm{~cm}$, dan tebal pelat beton $30,5 \mathrm{~cm}$.

\section{PENDAHULUAN}

Jalan Harun Thohir di Kecamatan Gresik, Kabupaten Gresik, Jawa Timur adalah salah satu akses menuju kawasan Pelabuhan Gresik. Berdasarkan administrasi pemerintahan dan beban muatan, Jalan Harun Thohir dikategorikan sebagai jalan kabupaten dan hanya mampu dilalui oleh kendaraan dengan dimensi dan beban gandar maksimum muatan sumbu terberat (MST) sebesar 8 ton [1]. Namun, ditengarai Jalan Harun Thohir dilalui oleh kendaraan-kendaraan berat yang memiliki beban lebih dari 8 ton. Hal ini menunjukkan bahwa beban lalu lintas yang terjadi pada Jalan Harun Thohir kemungkinan melebihi kapasitas seharusnya (tidak sesuai dengan perencanaan awal). Perlu dicatat bahwa lebihnya beban lalu lintas dapat menjadi salah satu penyebab terjadinya kerusakan perkerasan jalan.

Pada kenyataannya di lapangan, jalan sepanjang kurang lebih $1,2 \mathrm{~km}$ ini mengalami kerusakan berupa jalan yang bergelombang, berlubang, dan konstruksi beton yang hancur. Padahal perkerasan jalan merupakan lapisan perkerasan yang terletak di antara lapisan tanah dasar dan roda kendaraan yang berfungsi memberikan pelayanan kepada sarana transportasi dan selama masa pelayanannya diharapkan tidak terjadi kerusakan yang berarti [2]. Idealnya, suatu lapisan perkerasan menyediakan permukaan yang tetap rata, agar kendaraan dapat berjalan dan memperoleh kenyamanan yang cukup. Sedangkan berdasarkan bahan pengikatnya, konstruksi perkerasan jalan dibedakan menjadi perkerasan 
lentur (flexible pavement), perkerasan kaku (rigid pavement), dan perkerasan komposit (composite pavement) [3]. Perkerasan lentur adalah perkerasan yang menggunakan aspal sebagai bahan pengikatnya dan lapisan perkerasannya bersifat memikul dan menyebarkan beban lalu lintas ke tanah dasar. Perkerasan kaku adalah perkerasan yang menggunakan semen sebagai bahan pengikatnya, baik dengan atau tanpa tulangan, yang diletakkan di atas tanah dasar dengan atau tanpa lapis pondasi bawah, dan beban lalu lintas sebagian besar dipikul oleh pelat beton. Sedangkan perkerasan komposit adalah perkerasan kaku yang dikombinasikan dengan perkerasan lentur, berupa perkerasan lentur di atas perkerasan kaku maupun sebaliknya [4].

Mengacu pada hal tersebut, kerusakan-kerusakan perkerasan jalan di Jalan Harun Thohir, Kecamatan Gresik, Kabupaten Gresik, Jawa Timur perlu diperbaiki. Untuk mengetahui jenis perkerasan apa yang paling tepat untuk digunakan, akan dilakukan perbandingan perencanaan menggunakan perkerasan lentur, perkerasan kaku, dan perkerasan paving block pada seksi yang sama. Pertamatama, perlu diketahui terlebih dahulu karakteristik lalu lintas berdasarkan data dari survei lalu lintas. Apabila karakteristik lalu lintas sudah diketahui maka dilanjutkan dengan perencanaan konstruksi (tebal masing-masing jenis perkerasan) dan analisis biaya konstruksi dan pemeliharaan, sehingga dapat diketahui jenis perkerasan apa yang paling menguntungkan pada perbaikan kerusakan perkerasan jalan di Jalan Harun Thohir.

Masalah-masalah yang akan diselesaikan dalam Studi yaitu:

1) Bagaimana karakteristik lalu lintas di Jalan Harun Thohir pada saat ini dan umur rencana?

2) Berapa tebal struktur perkerasan lentur yang dibutuhkan untuk perbaikan kerusakan perkerasan jalan di Jalan Harun Thohir dengan umur rencana 20 tahun?

3) Berapa tebal struktur perkerasan kaku yang dibutuhkan untuk perbaikan kerusakan perkerasan jalan di Jalan Harun Thohir dengan umur rencana 40 tahun?

4) Berapa tebal struktur perkerasan paving block yang dibutuhkan untuk perbaikan kerusakan perkerasan jalan di Jalan Harun Thohir dengan umur rencana 20 tahun?

5) Berapa biaya konstruksi dan pemeliharaan yang diperlukan untuk masing-masing struktur perkerasan lentur, kaku, dan paving block?

6) Jenis perkerasan apakah yang sesuai untuk perbaikan kerusakan perkerasan jalan di Jalan Harun Thohir ditinjau dari sisi biaya konstruksi dan pemeliharaan?

\section{METODE PENELITIAN}

\section{A. Umum}

Tahap-tahap yang dilakukan dalam penyusunan Studi adalah:

1) Tahap persiapan

2) Tahap pengumpulan data

3) Tahap analisis

\section{B. Tahap Persiapan}

Tahap persiapan adalah tahap melakukan studi literatur. Literatur utama dalam Studi ini adalah Manual Desain Perkerasan 2017 [5]. Pada literatur tersebut diatur ketentuan-ketentuan mengenai perkerasan lentur dan kaku.
Sedangkan untuk perkerasan paving block mengacu pada jurnal yang menggunakan metode modifikasi perkerasan lentur, metode Australian empiris, dan mechanistic design [6].

\section{Tahap Pengumpulan Data}

Data-data yang digunakan pada Studi ini adalah data sekunder. Data sekunder adalah data yang diperoleh oleh peneliti dari sumber yang telah ada. Dalam Studi ini terdapat enam data sekunder, yaitu data jumlah penduduk, data produk domestik regional bruto (PDRB), data produk domestik regional bruto per kapita (PDRB per kapita), data lalu lintas, data curah hujan, dan data harga satuan pokok kegiatan (HSPK). Data jumlah penduduk, data PDRB, dan PDRB per kapita diperoleh dari BPS Jawa Timur [7] untuk meramalkan faktor pertumbuhan lalu lintas sesuai dengan umur rencana. Data lalu lintas diperoleh dari data survei lalu lintas sebelumnya untuk menghitung kumulatif lintasan sumbu standar ekivalen dan menentukan karakteristik lalu lintas. Data curah hujan diperoleh dari BPS Jawa Timur untuk penentuan faktor regional dalam menghitung lintas ekivalen rencana pada struktur perkerasan paving block. Sedangkan data HSPK digunakan untuk menghitung rencana anggaran biaya (RAB). Dalam Studi ini digunakan HSPK Kota Surabaya tahun 2018 [8] dan dilakukan beberapa penyesuaian menggunakan data harga satuan Kota Gresik tahun 2018 [9].

\section{Tahap Analisis Peninjauan Karakteristik Lalu Lintas}

Guna menghitung tebal struktur perkerasan kaku, lentur, dan paving block dalam perbaikan kerusakan perkerasan jalan di Jalan Harun Thohir, harus diketahui terlebih dahulu karakteristik lalu lintasnya. Pertama-tama, ditentukan umur rencana sesuai dengan ketentuan Manual Desain Perkerasan 2017 [5] untuk masing-masing jenis perkerasan. Kemudian, data jumlah penduduk, PDRB, dan PDRB per kapita diolah untuk meramalkan faktor pertumbuhan lalu lintas. Selanjutnya, faktor pertumbuhan lalu lintas dan data lalu lintas digunakan untuk menghitung kumulatif lintasan sumbu standar ekivalen. Dengan demikian, karakteristik lalu lintas Jalan Harun Thohir dapat diketahui.

\section{E. Perencanaan Tebal Struktur Perkerasan}

Setelah karakteristik lalu lintas diketahui berdasarkan tahapan sebelumnya, dapat direncanakan tebal struktur perkerasan dan drainase jalan.

\section{F. Perhitungan Biaya}

Setelah tebal struktur dari masing-masing jenis perkerasan diketahui berdasarkan tahapan sebelumnya, dapat dihitung volume pekerjaan sesuai dengan perencanaan tersebut. Kemudian, volume pekerjaan dikalikan dengan HSPK yang ada. Maka, akan diperoleh besarnya rencana anggaran biaya dari masing-masing jenis perkerasan.

\section{G. Pemilihan Jenis Perkerasan}

Pemilihan jenis perkerasan didasarkan pada biaya konstruksi dan pemeliharaan terendah/termurah dari masingmasing jenis perkerasan lentur, perkerasan kaku, dan perkerasan paving block.

\section{H. Bagan Alir}

Secara skematis, alur kegiatan yang akan dilakukan dalam penyusunan Studi ditunjukkan pada Gambar 1. 


\section{HASIL DAN DISKUSI}

\section{A. Karakteristik Lalu Lintas}

Sebelum merencanakan tebal struktur perkerasan, perlu diketahui terlebih dahulu karakteristik lalu lintas pada jalan yang ditinjau. Karakteristik lalu lintas dapat dinyatakan dengan kumulatif beban sumbu standar ekivalen (CESAL), yang merupakan hasil perkalian dari lintas harian rata-rata (LHR), faktor ekivalen beban (vehicle damage factor), 365 hari, faktor distribusi arah (DD), faktor distribusi lajur (DL), dan faktor pertumbuhan lalu lintas (R) [5].

Didapatkan hasil bahwa jenis kendaraan yang paling dominan melintas pada tahun 2018 adalah 1,2-2,2 Trailer, yaitu sebanyak 506 dari 1.686 kendaraan per hari $(30,012 \%)$. Namun, apabila ditinjau dari CESAL yang ditimbulkan, jenis kendaraan yang paling berpengaruh pada kerusakan perkerasan jalan adalah 1,22 Truk, yaitu sebesar 43,616\%. Perlu dicatat bahwa jenis kendaraan lainnya juga berpengaruh dalam kerusakan perkerasan jalan akibat adanya kelebihan muatan.

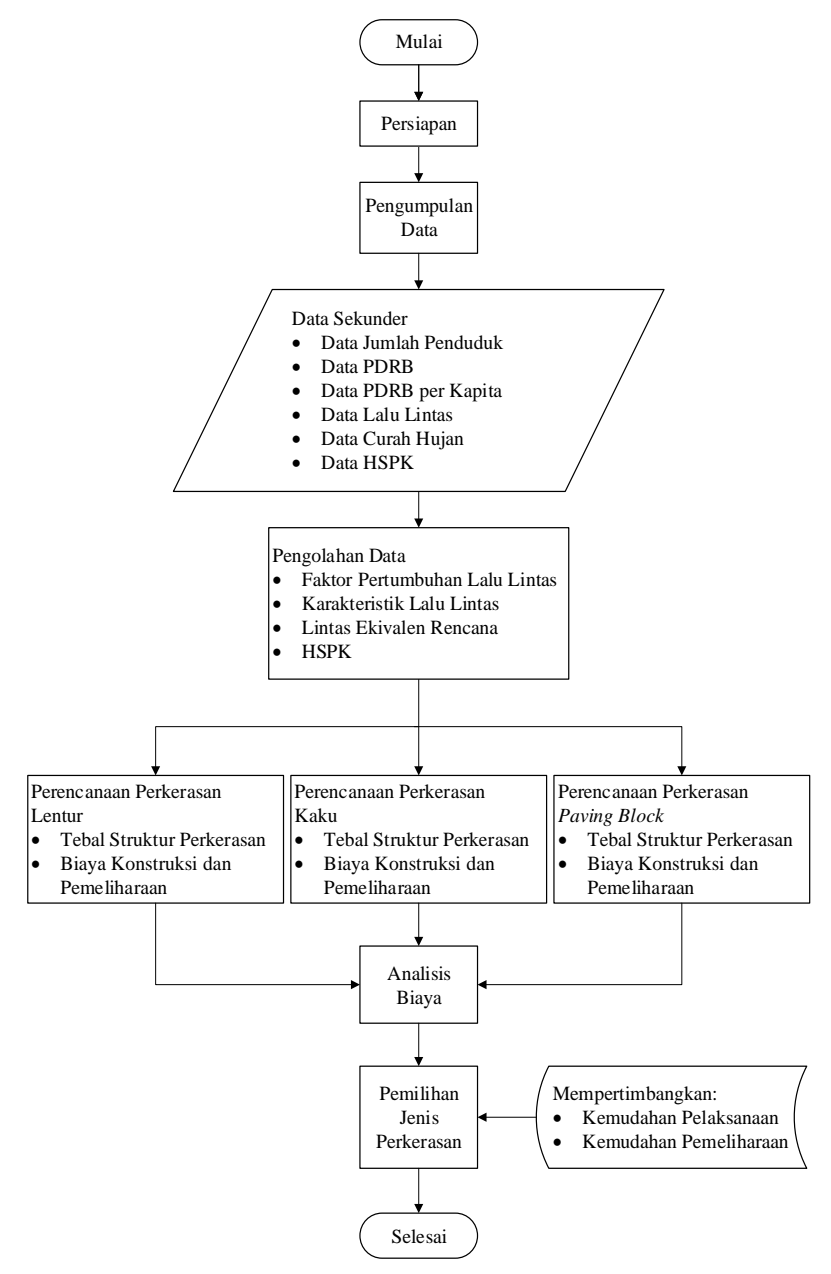

Gambar 1. Bagan alir penyusunan studi

\section{B. Perencanaan Tebal Perkerasan Lentur}

Perencanaan tebal perkerasan lentur menggunakan cement treated base (CTB). Berdasarkan perhitungan, diperoleh CESAL pada umur rencana 20 tahun (tahun 2038) sebesar 430.720.517,39 dan berdasarkan Tabel Desain Perkerasan Lentur Opsi Biaya Minimum dengan CTB digolongkan sebagai F5, yakni dalam rentang 200 juta s.d. 500 juta CESAL, dengan struktur perkerasan:

$$
\mathrm{AC} \mathrm{WC}=50 \mathrm{~mm}
$$
$\mathrm{AC} \mathrm{BC}$
$=60 \mathrm{~mm}$
AC base
$=220 \mathrm{~mm}$
CTB
$=150 \mathrm{~mm}$

Pondasi Agregat Kelas A $=150 \mathrm{~mm}$

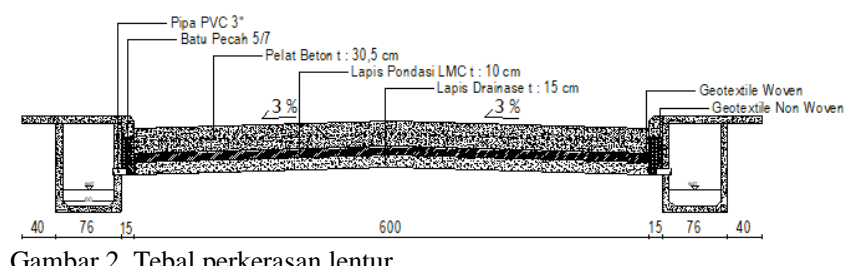

\section{Perencanaan Tebal Perkerasan Kaku}

Perencanaan tebal perkerasan kaku mengacu pada Tabel Perkerasan Kaku untuk Jalan dengan Beban Lalu Lintas Berat (persyaratan desain perkerasan kaku dengan sambungan dan ruji (dowel) serta bahu beton (tied shoulder), dengan atau tanpa tulangan distribusi retak), dengan melakukan perhitungan kelompok sumbu kendaraan berat (JKSN). Berikut ini adalah contoh perhitungan JKSN:

Diketahui LHR saat ini (tahun 2018) untuk konfigurasi sumbu 1,1 HP adalah 284 kendaraan dan jumlah sumbu adalah 2. Selain itu, telah diketahui pula R (40 tahun) untuk kendaraan pribadi adalah 40,40. Pertama-tama, dihitung JKSNH dengan mengalikan LHR dan jumlah sumbu kendaraan. Kemudian, kalikan JKSNH dengan R dan 365 hari.

(1)

JKSNH = LHR.jumlah sumbu kendaraan

$$
\begin{aligned}
= & 284.2 \\
= & 568 \\
& =\text { JKSNH.R.365 } \\
& \\
& =568.40,40.365 \\
& =8.374 .764,75
\end{aligned}
$$

Maka, untuk konfigurasi sumbu 1,1 HP memiliki JKSN sebesar 8.374.764,75. Apabila JKSN dari masing-masing konfigurasi sumbu telah dihitung, jumlahkan dan akan didapatkan JKSN total.

Berdasarkan perhitungan, diperoleh JKSN total sebesar 57.770.350,20 dan berdasarkan Tabel Perkerasan Kaku untuk Jalan dengan Beban Lalu Lintas Berat (persyaratan desain perkerasan kaku dengan sambungan dan ruji (dowel) serta bahu beton (tied shoulder), dengan atau tanpa tulangan distribusi retak), digolongkan dalam R5, yakni dengan rentang 43 juta s.d. 86 juta, dengan struktur perkerasan:

Tebal pelat beton $\quad=305 \mathrm{~mm}$

Lapis pondasi $\mathrm{LMC}=100 \mathrm{~mm}$

Lapis drainase $\quad=150 \mathrm{~mm}$

Direncanakan perkerasan kaku bersambung tanpa tulangan, sehingga akan digunakan dowel sebagai sambungan susut melintang dan sambungan pelaksanaan melintang. Mengacu pada Tabel Diameter Ruji, dikarenakan tebal pelat beton $(\mathrm{h})$ adalah $305 \mathrm{~mm}$, maka digolongkan pada no. 5 dengan rentang h 220 s.d. 250 mm dengan ketentuan sambungan susut melintang:

Kedalaman sambungan $=0,5 . \mathrm{h}$

$$
\begin{array}{ll} 
& =0,5.305 \mathrm{~mm} \\
& =152,5 \mathrm{~mm} \\
\text { Jarak sambungan } & =4 \mathrm{~m} \\
\text { Diameter ruji } & =36 \mathrm{~mm} \\
\text { Panjang ruji } & =45 \mathrm{~mm}
\end{array}
$$


Jarak antar ruji $\quad=30 \mathrm{~mm}$

Sedangkan untuk sambungan pelaksanaan melintang dengan tebal pelat beton $>17 \mathrm{~cm}$ memiliki ketentuan:

Kedalaman sambungan $=152,5 \mathrm{~mm}$

Diameter ruji $\quad=20 \mathrm{~mm}$

Panjang ruji $\quad=84 \mathrm{~mm}$

Jarak antar ruji $\quad=60 \mathrm{~mm}$

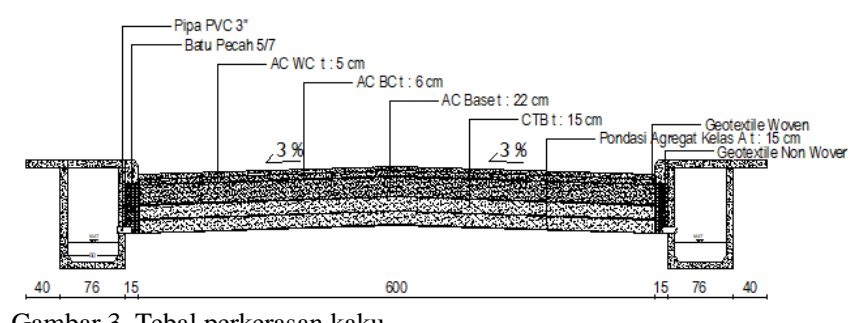

Gambar 3. Tebal perkerasan kaku.

\section{Perencanaan Tebal Perkerasan Paving Block}

Perencanaan tebal perkerasan paving block menggunakan metode modifikasi perkerasan lentur, metode australian empiris, dan mechanistic design. Secara umum, prinsip perhitungan sama dengan metode analisa komponen pada perencanaan struktur perkerasan lentur. Pertama-tama, dilakukan perhitungan LER. Berikut ini adalah contoh perhitungan LER:

Diketahui LHR pada tahun buka jalan (tahun 2018) untuk konfigurasi sumbu 1,1 HP adalah 284 kendaraan. Selain itu, telah diketahui pula VDF total adalah 0,00044. Direncanakan 1 lajur dengan lebar $3 \mathrm{~m}$ (asumsi jalan arteri), sehingga koefisien (C) adalah 1. Maka untuk konfigurasi 1,1 HP;

(4)

$$
\text { LEP }=\text { LHR.VDF.C }
$$

$$
\begin{aligned}
& =284 \cdot 0,00044 \cdot 1 \\
& =0,12 \\
\text { LEA } & =\mathrm{LEP}(1+\mathrm{i})^{\mathrm{UR}} \\
(5) & \\
& =0,12(1+0,05036)^{20} \\
& =0,33 \\
\text { LET } & =(\mathrm{LEP}+\mathrm{LEA}) / 2 \\
(6) & \\
= & (0,12+0,33) / 2 \\
& =0,23 \\
\text { LER } & =\text { LET.FP } \\
& =0,23 \cdot(20 / 10) \\
& =0,46
\end{aligned}
$$$$
\text { (6) }
$$

Hitung LER setiap konfigurasi sumbu seperti contoh, jumlahkan, dan akan diperoleh LER total. Berdasarkan perhitungan, diperoleh LER total sebesar 257.570,80. LER total akan digunakan saat menentukan ITP melalui pembacaan nomogram. Selain itu, ditentukan parameter yang akan digunakan dalam perencanaan tebal perkerasan paving block;
a. Surface (paving block $\mathrm{K} 450$ ) : $\mathrm{a}_{1}=0,44$
b. Lapisan sand bedding $\quad: \mathrm{a}_{2}=0,04$
c. Base (batu pecah kelas A) $\quad: \mathrm{a}_{3}=0,14$
d. Subbase (sirtu kelas A) $\quad: a_{4}=0,13$
e. Subgrade (asumsi CBR 60\%)
f. Indeks permukaan awal $\left(\mathrm{Ip}_{0}\right) \quad: 3,5$
g. Indeks permukaan akhir $\left(\mathrm{Ip}_{\mathrm{t}}\right): 2,5$

Daya dukung tanah (subgrade) diasumsikan memiliki CBR $60 \%$ atau setara dengan:

DDT $=4,3 \log (0,6)+1,7$

$$
\begin{gathered}
=4,3 \log (0,6)+1,7 \\
=9,35
\end{gathered}
$$

Digunakan FR sebesar 2 karena curah hujan $>900$ $\mathrm{mm} / \mathrm{tahun}$ (diperoleh 2.278,40 mm/tahun), kelandaian $<6 \%$, dan persentase kendaraan berat $>30 \%$ (diperoleh sebesar 83\%). Tabel 4.12 menunjukkan data curah hujan yang diperoleh dari BPS Jawa Timur.

Apabila LER, DDT, dan FR telah diketahui, maka indeks tebal perkerasan (ITP) dapat ditentukan. Dalam hal ini menggunakan nomogram 2 karena I $\mathrm{p}_{0}$ yang digunakan adalah 3,5 dan $\mathrm{Ip}_{\mathrm{t}}$ yang digunakan adalah 2,5. Dari nomogram 2 didapatkan nilai ITP sebesar 8,80.

Berdasarkan ketentuan tebal paving block dan Tabel Tebal Lapis Permukaan Minimum diketahui tebal minimum untuk masing-masing lapis;

$$
\begin{aligned}
& \mathrm{d}_{1}=10 \mathrm{~cm} \\
& \mathrm{~d}_{2}=5 \mathrm{~cm} \\
& \mathrm{~d}_{3}=20 \mathrm{~cm}
\end{aligned}
$$

Maka, untuk $\mathrm{d}_{4}$ berbahan sirtu kelas B:

ITP $=\mathrm{a}_{1} \mathrm{~d}_{1}+\mathrm{a}_{2} \mathrm{~d}_{2}+\mathrm{a}_{3} \mathrm{~d}_{3}+\mathrm{a}_{4} \mathrm{~d}_{4}$

$8,50=0,44.10+0,04.5+0,14.20+0,13 \cdot \mathrm{d}_{4}$

$\mathrm{d}_{4}=8,846 \mathrm{~cm}$ (tebal minimum adalah $10 \mathrm{~cm}$ ) $=10 \mathrm{~cm}$

Sehingga, tebal perkerasan paving block adalah:

$\mathrm{d}_{1}=10 \mathrm{~cm}$ (tebal paving block)

$\mathrm{d}_{2}=5 \mathrm{~cm}$ (tebal sand bedding)

$\mathrm{d}_{3}=20 \mathrm{~cm}$ (tebal base $;$ material batu pecah kelas A)

$\mathrm{d}_{4}=10 \mathrm{~cm}$ (tebal subbase; material sirtu kelas B)

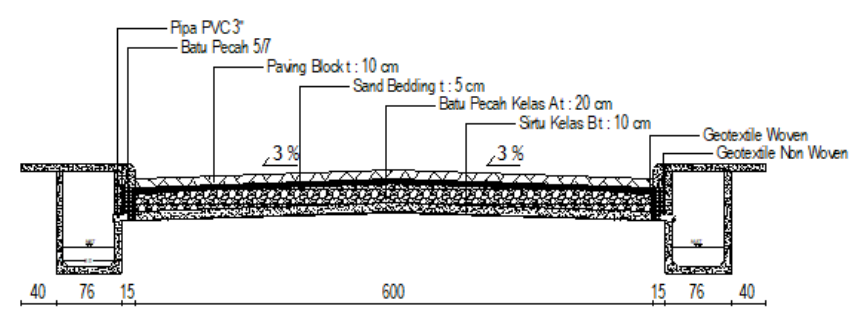

Gambar 4. Tebal perkerasan paving block

\section{E. Analisis Biaya}

Dihitung total biaya per meter untuk masing-masing jenis perkerasan dengan mengalikan volume serta nilai HSPK. Diperoleh hasil biaya konstruksi per meter perkerasan lentur Rp 1.391.534,70, perkerasan kaku Rp 1.435.018,69, dan perkerasan paving block $\mathrm{Rp} 1.246 .673,66$.

Diasumsikan biaya pemeliharaan per tahun untuk perkerasan lentur dan perkerasan paving block adalah 5\% dari initial cost, sedangkan perkerasan kaku sebesar $1 \%$ dari initial cost. Dilakukan penyesuaian nilai uang (time value of money).

$$
\begin{aligned}
\text { P perkerasan lentur }= & \mathrm{A}\left\{(1+\mathrm{i})^{\mathrm{n}}-1\right\} /\left\{\mathrm{i}(1+\mathrm{i})^{\mathrm{n}}\right\} \quad(10) \\
= & \left(5 \% \%^{*} 1391.534,70\right)^{*}\left\{(1+0,06)^{40}-1\right\} / \\
& \left.0,06(1+0,06)^{40}\right\} \\
= & 1.046 .872,21 \\
= & \mathrm{A}\left\{(1+\mathrm{i})^{\mathrm{n}}-1\right\} /\left\{\mathrm{i}(1+\mathrm{i})^{\mathrm{n}}\right\} \\
= & \left(1 \% \%^{*} 1.435 .018,69\right)^{*}\left\{(1+0,06)^{40}-1\right\} / \\
& \left\{0,06(1+0,06)^{40}\right\} \\
& =215.917,17 \\
\text { P perkerasan kaku } & \\
= & (5 \% * 1.246 .673,66)^{*}\left\{(1+0,06)^{40}-1\right\} / \\
& \left\{0,06(1+0,06)^{40}\right\} \\
= & 937.891,10
\end{aligned}
$$

Sehingga, total biaya per meter adalah:

Biaya perk. lentur $=2 * R p 1.391 .534,70+R p 1.046 .872,21$ 


$$
\begin{aligned}
& =\operatorname{Rp} 3.829 .941,62 \\
\text { Biaya perk. kaku } & =\operatorname{Rp} 1.435 .018,69+\operatorname{Rp} 215.917,17 \\
& =\operatorname{Rp} 1.650 .935,86 \\
\text { Biaya perk. paving } & =2 * \operatorname{Rp} 1.246 .673,66+\operatorname{Rp} 937.891,10 \\
& =\operatorname{Rp} 3.431 .238,41
\end{aligned}
$$

\section{F. Pemilihan Jenis Perkerasan}

Hasil analisis biaya menunjukkan bahwa jenis perkerasan dengan initial cost terendah adalah perkerasan paving block. Hal inilah yang mungkin dijadikan pertimbangan oleh pemerintah Kota Gresik dalam memilih perkerasan paving block sebagai jenis perkerasan yang sesuai untuk perbaikan kerusakan perkerasan jalan di Jalan Harun Thohir saat ini.

Sedangkan apabila ketiga jenis perkerasan dihitung dengan umur rencana 40 tahun, perkerasan kaku adalah jenis perkerasan dengan biaya konstruksi dan pemeliharaan per meter terendah. Walaupun initial cost perkerasan kaku lebih tinggi dibandingkan dengan perkerasan lentur dan perkerasan paving block, namun initial cost tersebut adalah untuk umur rencana 40 tahun dan pemeliharaan perkerasan kaku tidak membutuhkan biaya yang besar, yakni $1 \%$ dari initial cost. Lain halnya dengan perkerasan kaku, perkerasan lentur dan perkerasan paving block hanya memiliki umur rencana 20 tahun, sehingga pada tahun ke-21 diasumsikan akan terdapat initial cost kembali akibat dilakukannya perencanaan ulang perbaikan perkerasan. Selain itu, perkerasan lentur dan perkerasan paving block membutuhkan biaya pemeliharaan per tahun yang lebih besar dibandingkan perkerasan kaku, yakni 5\% dari initial cost, untuk melakukan pekerjaan overlay. Sehingga, apabila diakumulasi selama 40 tahun, didapatkan biaya konstruksi dan pemeliharaan per meter untuk perkerasan kaku lebih rendah dibandingkan dengan perkerasan lentur dan perkerasan paving block. Maka, dengan mempertimbangkan besarnya biaya yang akan dikeluarkan pada saat ini hingga mendatang selama 40 tahun, perbaikan kerusakan perkerasan jalan di Jalan Harun Thohir, Kecamatan Gresik, Kabupaten Gresik, Jawa Timur, dipilih menggunakan perkerasan kaku.

\section{KESIMPULAN}

1) Jenis kendaraan yang paling dominan melintas di Jalan Harun Thohir adalah 1,2-2,2 Trailer (30,012\%). Namun, apabila ditinjau dari CESAL yang ditimbulkan, jenis kendaraan yang paling berpengaruh pada kerusakan perkerasan jalan pada saat ini maupun pada umur rencana 20 dan 40 tahun adalah 1,22 Truk (43,616\%).

2) Tebal struktur perkerasan lentur yang dibutuhkan untuk perbaikan kerusakan perkerasan jalan di Jalan Harun Thohir dengan umur rencana 20 tahun adalah pondasi agregat kelas A $15 \mathrm{~cm}, \mathrm{CTB} 15 \mathrm{~cm}, \mathrm{AC} \mathrm{BC}$ atau $\mathrm{AC}$ base $22 \mathrm{~cm}$, AC BC $6 \mathrm{~cm}$, dan AC WC $5 \mathrm{~cm}$.

3) Tebal struktur perkerasan kaku yang dibutuhkan untuk perbaikan kerusakan perkerasan jalan di Jalan Harun Thohir dengan umur rencana 40 tahun adalah lapis drainase $15 \mathrm{~cm}$, lapis pondasi LMC $10 \mathrm{~cm}$, dan tebal pelat beton $30,5 \mathrm{~cm}$.

4) Tebal struktur perkerasan paving block yang dibutuhkan untuk perbaikan kerusakan perkerasan jalan di Jalan Harun Thohir dengan umur rencana 20 tahun adalah sirtu kelas B $10 \mathrm{~cm}$, batu pecah kelas A $20 \mathrm{~cm}$, sand bedding $5 \mathrm{~cm}$, dan paving block $10 \mathrm{~cm}$.

5) Biaya konstruksi dan pemeliharan per meter (umur rencana 40 tahun) untuk perkerasan lentur sebesar $\mathrm{Rp}$ 3.829.941,62, perkerasan kaku sebesar Rp 1.650.935,86, dan perkerasan paving block sebesar Rp $3.431 .238,41$.

6) Jenis perkerasan yang sesuai untuk perbaikan kerusakan perkerasan jalan di Jalan Harun Thohir ditinjau dari sisi biaya konstruksi dan pemeliharaan dengan mempertimbangkan kemudahan pelaksanaan dan pemeliharaan, yaitu perkerasan kaku.

\section{DAFTAR PUSTAKA}

[1] Dewan Perwakilan Rakyat Republik Indonesia dan Presiden Republik Indonesia, "Undang-Undang Republik Indonesia Nomor 22 Tahun 2009 tentang Lalu Lintas dan Angkutan Jalan,” Jakarta, 2009.

[2] S. Sukirman, Beton Aspal Campuran Panas. Jakarta: Granit, 2003.

[3] S. Silvia, Perkerasan Lentur Jalan Raya. Bandung: Nova Publisher, 1999.

[4] S. Sukirman, Dasar - Dasar Perencanaan Geometrik Jalan. NOVA, 1999.

[5] Direktorat Jenderal Bina Marga, "Manual Perkerasan Jalan 2017," Jakarta, 2017.

[6] P. Kefie, A. Suryadharma, I. Santoso, and B. Proboyo, "Perancangan Perkerasan Concrete Block dan Estimasi Biaya," Surabaya.

[7] Badan Pusat Statistik Kabupaten Gresik, "Profil Kabupaten Gresik 2017," Gresik, 2017.

[8] T. Rismaharini, "Lampiran II Keputusan Walikota Surabaya Daftar Harga Satuan Pokok Kegiatan (HSPK)," Surabaya, 2018.

[9] S. H. Radianto, "Lampiran I Keputusan Bupati Gresik Tentang Standar Harga Satuan Barang/Jasa Konstruksi, Pedoman Analisa Harga Satuan Pekerjaan Pemerintah, dan Harga Satuan Bangunan Gedung Negara Kabupaten Gresik Semester II Tahun 2018," Gresik, 2018. 